\title{
Pre-harvest glyphosate desiccation on barley seed quality
}

\author{
Dessecação com glifosato em pré collheita na qualidade de sementes de cevada \\ Desecación con glifosato antes de la cosecha en la calidad de semillas de cebada
}

Received: 05/24/2021 | Reviewed: 06/01/2021 | Accept: 06/05/2021 | Published: 06/20/2021

\author{
Maximiliano Kawahata Pagliarini \\ ORCID: https://orcid.org/0000-0001-7408-6327 \\ Universidade Federal da Grande Dourados, Brasil \\ E-mail: mpagliarini@ufgd.edu.br \\ Marisa Cáceres Rebouças \\ ORCID: https://orcid.org/0000-0002-6916-9600 \\ Centro Universitário da Grande Dourados, Brasil \\ E-mail: agricola.marisacr@gmail.com \\ Kamila de Almeida Monaco-Mello \\ ORCID: https://orcid.org/0000-0002-6118-2640 \\ Universidade Federal da Grande Dourados, Brasil \\ E-mail: kamilamonaco@ufgd.edu.br \\ Patricia dos Santos Zomerfeld \\ ORCID: https://orcid.org/0000-0001-8590-839X \\ Universidade Federal da Grande Dourados, Brasil \\ E-mail: patricia.zomerfeld@gmail.com \\ Bruno Cezar Alvaro Pontim \\ ORCID: https://orcid.org/0000-0002-3370-8916 \\ Universidade Federal da Grande Dourados, Brasil \\ E-mail: brunopontim@ufgd.edu.br \\ Carla Regina Baptista Gordin \\ ORCID: https://orcid.org/0000-0003-1781-699X \\ Universidade Federal da Grande Dourados, Brasil \\ E-mail: carlagordin@ufgd.edu.br \\ Euclydes Minella \\ ORCID: https://orcid.org/0000-0001-8224-1286 \\ Empresa Brasileira de Pesquisa Agropecuária Trigo, Brasil \\ E-mail: euclydes.minella@embrapa.br
}

\begin{abstract}
The experiment was conducted into two stages, the first being the barley seed production and application of glyphosate and the second the vigour tests in the laboratory. Both stages were performed at the Experimental Farm of Agrarian Sciences at Grand Dourados Federal University (UFGD). In field, four cultivars of barley was sowing being: BRS Cryst, BRS Kallibre, BRS Demeter, BRS Sampa. For desiccation, the glyphosate herbicide (480 g L $\mathrm{g}^{-1}$ active ingredient) was used, applied using a backpack sprayer at dose of $5 \mathrm{~L} \mathrm{ha}^{-1}$. The experimental design used was randomized blocks, and each cultivar was divided into five replications, applying the herbicide in four of them leaving one without application for control. The application was made when seeds presented water content close to $50 \%$. At second stage, eight evaluation were made being one at the day of glyphosate application, one, two, three, eight, ten and fourteen days after application and without application in natural physiological maturity. In each evaluation, sowing was performed according to Rules to Seed Analysis. The analyses were: First count, percentage of germination, germination speed index, mean germination time, mean germination speed, accelerated aging and synchronization index. Glyphosate has interfered negatively in the physiological maturation of barley seeds when the herbicide was applied in pre-harvest. The results obtained showed that there was an increase in seeds germination after 14 days of application, however, the means were significantly smaller in relation to seeds harvested at the point of physiological maturation without glyphosate application.
\end{abstract}

Keywords: Hordeum vulgare L.; Vigour test; Rules to seeds Analysis; Barley cultivars.

\section{Resumo}

O experimento foi realizado em duas etapas, sendo a primeira a produção de sementes de cevada e aplicação de glifosato e a segunda os testes de vigor em laboratório. As duas etapas foram realizadas na Fazenda Experimental de Ciências Agrárias da Universidade Federal de Grande Dourados (UFGD). No campo, foram semeadas quatro cultivares de cevada sendo: BRS Cryst, BRS Kallibre, BRS Demeter, BRS Sampa. Para a dessecação, foi utilizado o herbicida glifosato (480 $\mathrm{g} \mathrm{L}^{-1}$ de ingrediente ativo), aplicado em pulverizador costal na dose de $5 \mathrm{~L} \mathrm{ha}^{-1}$. O delineamento experimental utilizado foi em blocos ao acaso, e cada cultivar foi dividida em cinco repetições, aplicando-se o herbicida em quatro delas, deixando uma sem aplicação para controle. A aplicação foi feita quando as 
sementes apresentavam teor de água próximo a 50\%. Na segunda etapa, foram feitas oito avaliações, sendo uma no dia da aplicação do glifosato, um, dois, três, oito, dez e quatorze dias após a aplicação e sem aplicação na maturidade fisiológica natural. Em cada avaliação, a semeadura foi realizada de acordo com as Regras para Análise de Sementes. As análises foram: primeira contagem, porcentagem de germinação, índice de velocidade de germinação, tempo médio de germinação, velocidade média de germinação, envelhecimento acelerado e índice de sincronização. $O$ glifosato interferiu negativamente na maturação fisiológica das sementes de cevada quando o herbicida foi aplicado em pré colheita. Os resultados obtidos mostraram que houve aumento na germinação das sementes após 14 dias da aplicação, porém, as médias foram significativamente menores em relação às sementes colhidas no ponto de maturação fisiológica sem aplicação de glifosato.

Palavras-chave: Hordeum vulgare L.; Teste de vigor; Regras para análises de sementes; Cultivares de cevada.

\section{Resumen}

El experimento ocurrió en dos etapas, la primera siendo la producción de semillas de cebada y la aplicación de glifosato y la segunda las pruebas de vigor en el laboratorio. Las dos etapas se llevaron a cabo en la Hacienda Experimental de Ciencias Agrícolas de la Universidad Federal de Grande Dourados (UFGD). En el campo se sembraron cuatro cultivares de cebada: BRS Cryst, BRS Kallibre, BRS Demeter, BRS Sampa. Para la desecación se utilizó el herbicida glifosato (480 $\mathrm{g} \mathrm{L}^{-1}$ de ingrediente activo), aplicado en spray costal a una dosis de $5 \mathrm{~L} \mathrm{ha}{ }^{-1}$. El diseño experimental utilizado fue en bloques al acaso, y cada cultivar se dividió en cinco repeticiones, aplicándose el herbicida en cuatro de ellas, quedando una sin aplicación para control. La aplicación se realizó cuando las semillas tenían un contenido de agua cercano al 50\%. En la segunda etapa se realizaron ocho evaluaciones, una el día de la aplicación del glifosato, uno, dos, tres, ocho, diez y catorce días después de la aplicación y sin aplicación en la madurez fisiológica natural. En cada evaluación, la siembra se realizó de acuerdo con las Reglas para el Análisis de Semillas. Los análisis fueron: primer conteo, porcentaje de germinación, índice de velocidad de germinación, tiempo promedio de germinación, velocidad promedio de germinación, envejecimiento acelerado e índice de sincronización. El glifosato tuvo un efecto negativo sobre la maduración fisiológica de las semillas de cebada cuando se aplicó el herbicida antes de la cosecha. Los resultados obtenidos mostraron que hubo un aumento en la germinación de las semillas a los 14 días de la aplicación, sin embargo, los promedios fueron significativamente menores en relación a las semillas cosechadas en el punto de maduración fisiológica sin aplicación de glifosato.

Palabras clave: Hordeum vulgare L.; Prueba de vigor; Reglas para el análisis de semillas; Cultivares de cebada.

\section{Introduction}

Barley (Hordeum vulgare L.), in Brazil, is produced almost exclusively for beer purposes, and, as winter crop, its cultivation is concentrated at states of Paraná, Rio Grande do Sul and Santa Catarina. Due to great existing demand, mainly from malting industry, barley grains production, in the country, is insufficient to supply the demand, which is supplied through imports (Narwal et al., 2020).

Like other cultivated species, barley needs effective and continuous research support (Pessenti et al., 2021), such as in the application of new technologies to improve productive potential expression with the increase of profitability and seeds quality (Tavares et al., 2018).

These topic is very important for all crops system production, as it is the beginning of process. Therefore, good seeds may improve yield significantly. The use of high quality seeds significantly influences crops yield components, which can cause an increase of up to $15 \%$ in productivity when compared to low quality seeds (Bagateli et al., 2019; Vergara et al., 2020).

In order to obtain high quality seeds, the different stages of production process must be observed, highlighting, initial quality of seed obtained in field, drying and processing and the storage environment. The association of these stages determines the production of seeds of superior quality (Vergara et al., 2020).

In relation to seeds obtained in field it is necessary to care about physiologic maturity that involve the harvest time. The physiological maturity may vary according to cultivar and environmental conditions, being necessary to establish parameters for correct definition of harvest season, called maturation indices (Oliveira \& Morais, 2019). The obtaining of seeds with high quality depends on the precise identification of the ideal harvest moment, which often corresponds to the time when physiological maturity is reached, also coinciding with the moment of maximum dry mass accumulation, high vigour and high germination potential (Carvalho and Nakagawa, 2000). 
Due to the variation in the relative humidity of the air and delay in the harvest, damage to the grains can occur, thus increasing the percentage of cracking and wrinkling of the integument, which increase the deterioration process, facilitating the penetration of pathogens and greater exposure of the embryonic tissue to the environment (Seidler et al., 2019). To achieve uniform physiological maturity, rapidly decrease grains water content, minimize their deterioration in the field and guaranteeing productivity is the application of desiccant herbicides in the pre-harvest.

Regarding the correct time for desiccation to occur, for Marcos Filho (2015), the herbicides used as desiccants must be applied from the moment the seeds reach their physiological maturity, thus providing a quick drying and uniformity at the stand, which ends up reducing the impurity index and the costs of grains drying. In addition to being responsible for increasing crops productivity, guaranteeing the harvest anticipation allowing the implantation of another crop.

However, the practice of applying herbicides while the plant is metabolically active may result in losses at harvest time and in seed quality, as the plant was unable to finish the seed maturation process causing embryo malformation that will not have vigour to emerge after sowing. Therefore, it is important to evaluate the consequences of applying different herbicides.

Glyphosate is one of them and is a systemic herbicide that inhibits the enzyme EPSPs (5-enolpiruvoil-shikimato-3phosphate synthetase), with a wide range of recommendations and effectiveness and has supported the control of a broad spectrum of weed control (Zavariz et al., 2020).

According to Wild et al. (1987), plants treated with glyphosate quickly accumulate ammonia, which act in chloroplasts destruction, reducing photosynthesis levels and reducing amino acids production, causing photosynthesis inhibition and cell death. Brunharo et al. (2014), highlighted that, plants submitted to glyphosate application present in the order chlorosis of treated tissue, followed by necrosis and subsequent plants death after a few days.

The objective of these work was to evaluate barley seed quality submitted to pre-harvest dessication with glyphosate.

\section{Methodology}

The experiment was divided into two stages, the first being the barley cultivation in the field and application of glyphosate and the second the vigour tests in the laboratory. Both stages were performed at the Experimental Farm of Agrarian Sciences at Grand Dourados Federal University (UFGD), located at latitude of $22^{\circ} 13^{\prime} 52,4495^{\prime}$, longitude of 54 59' 10,5372 ", altitude of $411,75 \mathrm{~m}$. The region climate, according to Köppen, is described as wet mesothermal Cwa. Average annual precipitation is $1,500 \mathrm{~mm}$ and mean temperature is $22^{\circ} \mathrm{C}$. The soil is classified as a dystrophic Red Latosol (Santos et al., 2018).

In field, four cultivars of barley was sowing being: BRS Cryst, BRS Kallibre, BRS Demeter, BRS Sampa. The soil preparation was conventional, being a plowing and two harrows. Fertilization was performed using $450 \mathrm{~kg} \mathrm{ha}^{-1}$ of the fertilizer formulated 04-30-10 in the planting line and application of $60 \mathrm{~kg} \mathrm{ha}^{-1}$ of $\mathrm{N}$ (urea was used as a source of $\mathrm{N}$ ) when the plant had 6 to 8 leaves.

For desiccation, the glyphosate herbicide ( $480 \mathrm{~g} \mathrm{~L}^{-1}$ of active ingredient) was used, applied using a backpack sprayer, equipped with fan-type tips, pressure of $2.0 \mathrm{kgf} \mathrm{cm}^{-2}$ and $200 \mathrm{~L} \mathrm{ha}^{-1}$ spray volume.

The experimental design used was randomized blocks, and each cultivar was divided into five replications, applying the herbicide at dose $5 \mathrm{~L} \mathrm{ha}^{-1}$ in four of them leaving one without application for control. The application was made when seeds presented water content close to $50 \%$. This measurement was performed by forced air circulation greenhouse method (Brasil, 2009).

The vigour analyses were performed at the Laboratory of Research, Teaching and Extension Support at Experimental Farm of Agrarian Sciences at UFGD, located at the same place where the first stage of experiment was conducted. 
At second stage, eight evaluation were made being one at the day of glyphosate application (105 days after sowing DAS); one, two, three, eight, ten and fourteen days after application (DAA) and without application in natural physiological maturity (128 DAS).

In each evaluation, sowing was performed between "germitest" papers moistened to 2.5 times the dry mass (g) of substrate. The paper rolls were kept in a B.O.D. (Biochemical Oxigen Demand) germinator type at a temperature of $20^{\circ} \mathrm{C}$ under constant white light, for seven days inside plastic bags (Brasil, 2009).

The analyses were: First count - the amount of germinated seeds in the first count was performed four days after sowing (Brasil, 2009), transforming the value in percentage.

Percentage of germination - the amount of germinated seeds at the end of test period was performed seven days after sowing (Brasil, 2009), transforming the value into a percentage.

Germination speed index (Maguire, 1962) - symbolized by GSI, in which the number of normal seeds or seedlings was counted during the seven days of the test duration, according to the formula below:

$$
\mathrm{IVG}=\mathrm{G} 1 / \mathrm{N} 1+\mathrm{G} 2 / \mathrm{N} 2+\ldots \mathrm{Gn} / \mathrm{Nn}
$$

Where: $\mathrm{G} 1, \mathrm{G} 2, \ldots \mathrm{Gn}=$ number of germinated seeds at the day of observation and $\mathrm{N} 1, \mathrm{~N} 2, \ldots \mathrm{Nn}=$ number of days after sowing.

Mean germination time - calculated using the formula presented by Edmond and Drapalla (1958), symbolized by MGT:

$$
\mathrm{MGT}=(\mathrm{N} 1 \mathrm{G} 1+\mathrm{N} 2 \mathrm{G} 2+\ldots+\mathrm{Nn} . \mathrm{Gn}) /(\mathrm{G} 1+\mathrm{G} 2+\ldots+\mathrm{Gn})
$$

Where: $\mathrm{G} 1, \mathrm{G} 2, \ldots \mathrm{Gn}=$ number of germinated seeds at the day of observation and $\mathrm{N} 1, \mathrm{~N} 2, \ldots \mathrm{Nn}=$ number of days after sowing. The results were expressed in days.

Mean germination speed (MGS) - calculated using the formula MGS = 1 / MGT, where: MGT is mean germination time calculated previously. The results were expressed in days ${ }^{-1}$.

Seedling length - determined using the mean of 10 plants per plot. They were measured from the apex of the largest primary root to the end of the primary leaves. The results were expressed in millimeters per seedlings.

Accelerated aging (AA) - the procedure to determine this variable was the same used to normal germination test in relation to sowing, according to line eight of this section. However, before sowing, seeds were kept on aluminum screen, fixed in a plastic germination box $(11 \times 11 \times 3.5 \mathrm{~cm})$, containing $40 \mathrm{~mL}$ of distilled water at the bottom. The boxes containing the seeds were closed and kept at $41^{\circ} \mathrm{C}$, for 24 hours. Normal seedlings were counted seven days after sowing, transforming the result into a percentage.

Synchronization index - Calculated according to the methodology cited by Labouriau and Pacheco (1978):

$$
E=-\Sigma \text { fi. } \log _{2} \text { fi }
$$

Where: $\mathrm{fi}=$ relative germination frequency $(\mathrm{RGF})$ and $\log _{2}=$ base 2 logarithm. The results were expressed in bits.

Data were submitted to analysis of variance and in the case of significance at $5 \%$ of probability means were compared by Tukey test by Sisvar computer program (Ferreira, 2019).

\section{Results}

At Table 1, it is possible to analyse the first count (\%) of barley germinated seeds, four days after sowing, in three different harvest situations: seeds harvested at plants submitted to pre-harvest dessication with glyphosate $\left(480 \mathrm{~g} \mathrm{~L}^{-1} \mathrm{of}_{\text {active }}\right.$ 
ingredient) at dose $5 \mathrm{~L} \mathrm{ha}^{-1}$, sampled in six different time after application (DAA - Days after application); seeds harvested at plants before glyphosate application (105 DAS - Days after sowing in field) and seeds harvested at plants without application (128 DAS - Days after sowing in field) and it is notable the difference among them all.

Analysing each treatment with or without glyphosate application we noticed that before application (105 DAS) the first count was very low, $7 \%$ for BRS Cryst; $4.5 \%$ for BRS Kallibre and zero for BRS Demeter and BRS Sampa which implied that seeds presented water content close to $50 \%$ did not have mature embryo.

The cultivars presented same behaviour, increasing the percentage of germinated seeds at first count over the period after application an also without application. In this case, all cultivars presented smaller percentage comparing the results with and without glyphosate application. In addition to this, after 14 days of application all cultivars have increased the number of germinated seeds comparing to other evaluation, however, presented less than at physiologic maturity.

Table 1. Percentage of germinated barley seeds in first count, four days after sowing, in three different harvest situations: seeds harvested at plants submitted to pre-harvest dessication with glyphosate (480 $\mathrm{g} \mathrm{L}^{-1}$ of active ingredient) at dose $5 \mathrm{~L} \mathrm{ha}^{-1}$, sampled in six different time after application (DAA - Days after application); seeds harvested at plants before glyphosate application (105 DAS - Days after sowing in field) and seeds harvested at plants without application (128 DAS - Days after sowing in field).

\begin{tabular}{|c|c|c|c|c|c|c|c|c|c|}
\hline \multirow[b]{3}{*}{ Cultivar } & \multicolumn{8}{|c|}{ First count $-\%$} & \multirow{3}{*}{$\begin{array}{l}\text { Without } \\
\text { application } \\
\text { (128 DAS) }\end{array}$} \\
\hline & \multirow{2}{*}{$\begin{array}{c}\text { Before } \\
\text { application } \\
\text { (105 DAS) }\end{array}$} & & \multicolumn{6}{|c|}{ Days after application (DAA) } & \\
\hline & & & 1 & 2 & 3 & 8 & 10 & 14 & \\
\hline BRS Cryst & $7.0 \mathrm{a}$ & $\mathrm{C}$ & $9.0 \mathrm{~b} \mathrm{C}$ & $7.5 \mathrm{~b} \mathrm{C}$ & $5.5 \mathrm{~b} \mathrm{C}$ & $10.5 \mathrm{~b} \mathrm{C}$ & $31.5 \mathrm{~b} \quad \mathrm{~B}$ & $27.5 \mathrm{~d} \mathrm{~B}$ & $83.0 \quad \mathrm{~b} \quad \mathrm{~A}$ \\
\hline BRS Kallibre & $4.5 \mathrm{a}$ & $\mathrm{F}$ & $15.0 \mathrm{a} \mathrm{E}$ & 15.0 a $\mathrm{E}$ & $14.0 \mathrm{a} \mathrm{E}$ & 29.00 a D & 45.0 a $\mathrm{C}$ & 61.5 a $\mathrm{B}$ & 93.0 a $\mathrm{A}$ \\
\hline BRS Demeter & $0.0 \mathrm{~b}$ & $\mathrm{E}$ & $4.5 \mathrm{~b} \quad \mathrm{E}$ & $2.5 \mathrm{~b} \quad \mathrm{E}$ & $4.5 \mathrm{~b} \quad \mathrm{E}$ & 25.0 a $\mathrm{C}$ & $16.5 \mathrm{c} \mathrm{D}$ & $53.5 \mathrm{~b} \quad \mathrm{~B}$ & 97.5 a $\mathrm{A}$ \\
\hline BRS Sampa & $0.0 \mathrm{~b}$ & $\mathrm{E}$ & $3.5 \mathrm{~b} \mathrm{E}$ & $11.5 \mathrm{a} \mathrm{D}$ & $5.0 \mathrm{~b} E$ & 24.0 a C & $29.0 \mathrm{~b} \mathrm{C}$ & 44.5 c B & 88.0 b A \\
\hline $\mathrm{CV}(\%)$ & & & & & & & & & \\
\hline
\end{tabular}

The means followed by same lower case letters in the columns and capital letter in the lines do not differ statistically from each other at $5 \%$ probability level for Scott-Knott test. Source: Authors.

As first count, the percentage of germination, at the of experiment (7 DAS), also presented statistical difference among treatments. At Table 2 it is possible to note that the number of germinated seed was increasing as the days passed after application. However, the difference between 14 DAA and the treatment without application was huge, BRS Cryst and BRS Sampa were the cultivar that reduced more $(37,1 \%$ and $35,4 \%$, respectively).

The evaluation 14 DAA and without application (128 DAS) were considered the harvest day for each treatment. The first one, the harvest would be 119 DAS, only nine days between them. 
Table 2. Percentage of germinated seeds of barley at the end of experiment, seven days after sowing, in three different harvest situations: seeds harvested at plants submitted to pre-harvest dessication with glyphosate (480 $\mathrm{g} \mathrm{L}^{-1}$ of active ingredient) at dose $5 \mathrm{~L} \mathrm{ha}^{-1}$, sampled in six different time after application (DAA - Days after application); seeds harvested at plants before glyphosate application (105 DAS - Days after sowing in field) and seeds harvested at plants without application (128 DAS Days after sowing in field).

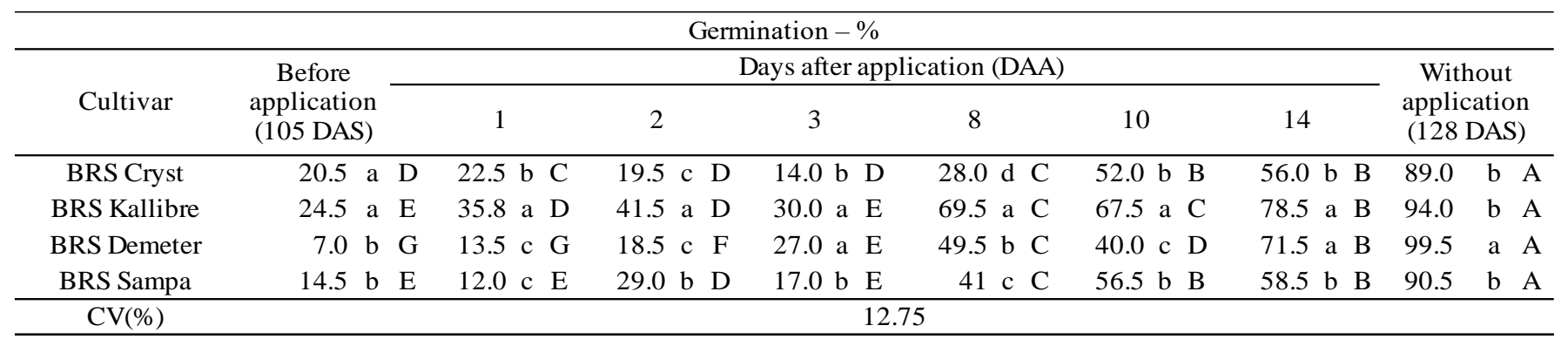

The means followed by same lower case letters in the columns and capital letter in the lines do not differ statistically from each other at 5\% probability level for Scott-Knott test. Source: Authors.

The Germination Speed Index (GSI) also kept the behaviour of first count and percentage of germination (Table 3). Comparing the results before application (105 DAS) and without application (128 DAS) the reduction of GSI was drastic. BRS Demeter have decreased $98,4 \%$ in relation to this index, followed by BRS Sampa with reduction of 96,1\%, BRS Kallibre with 91,9\% and BRS Cryst with $89,7 \%$.

After application, it was possible to report that the GSI have increased over the time for all cultivars, however, comparing to seeds harvest at natural maturity age the GSI reduction was notable being $68,6 \%$ for BRS Cryst; 59,8\% for BRS Demeter; $56,6 \%$ for BRS Sampa and 52,3\% for BRS Kallibre.

Table 3. Germination Speed Index (GSI) of barley seed at the end of experiment, seven days after sowing, in three different harvest situations: seeds harvested at plants submitted to pre-harvest dessication with glyphosate $\left(480 \mathrm{~g} \mathrm{~L}^{-1}\right.$ of active ingredient) at dose $5 \mathrm{~L} \mathrm{ha}^{-1}$, sampled in six different time after application (DAA - Days after application); seeds harvested at plants before glyphosate application (105 DAS - Days after sowing in field) and seeds harvested at plants without application (128 DAS - Days after sowing in field).

\begin{tabular}{|c|c|c|c|c|c|c|c|c|c|}
\hline \multicolumn{10}{|c|}{ GSI (Germination Speed Index) } \\
\hline \multirow{2}{*}{ Cultivar } & \multirow{2}{*}{\multicolumn{2}{|c|}{$\begin{array}{c}\text { Before } \\
\text { application } \\
\text { (105 DAS) }\end{array}$}} & \multicolumn{6}{|c|}{ Days after application (DAA) } & \multirow{2}{*}{$\begin{array}{l}\text { Without } \\
\text { application } \\
\text { (128 DAS) }\end{array}$} \\
\hline & & & 1 & 2 & 3 & 8 & 10 & 14 & \\
\hline BRS Cryst & $5.43 \mathrm{a}$ & $\mathrm{D}$ & 6.74 b D & $5.70 \mathrm{~b} \quad \mathrm{D}$ & $4.47 \mathrm{~b} \mathrm{D}$ & $7.84 \mathrm{~d} \mathrm{D}$ & $21.54 \mathrm{~b} \mathrm{~B}$ & 16.51 c $\mathrm{C}$ & $52.62 \mathrm{~d} \mathrm{~A}$ \\
\hline BRS Kallibre & $5.12 \mathrm{a}$ & $\mathrm{F}$ & 10.60 a $\mathrm{E}$ & 10.57 a $\mathrm{E}$ & 11.46 a $\mathrm{E}$ & 21.58 a $\mathrm{D}$ & 34.34 a B & 30.22 a $\mathrm{C}$ & 63.44 b A \\
\hline BRS Demeter & $1.13 \mathrm{~b}$ & $\mathrm{D}$ & 3.74 c D & $3.15 \mathrm{~b} \quad \mathrm{D}$ & $5.69 \mathrm{~b} \mathrm{D}$ & $16.26 \mathrm{~b} \mathrm{C}$ & $13.66 \mathrm{c} \mathrm{C}$ & 28.72 a $\mathrm{B}$ & 71.52 a $\mathrm{A}$ \\
\hline BRS Sampa & $2.21 \mathrm{~b}$ & $\mathrm{E}$ & 2.74 c E & 8.23 a D & $4.65 \mathrm{~b} \mathrm{E}$ & 13.46 с C & $22.11 \mathrm{~b} \mathrm{~B}$ & $24.39 \mathrm{~b}$ B & 56.17 c $A$ \\
\hline $\mathrm{CV}(\%)$ & \multicolumn{9}{|c|}{12.99} \\
\hline
\end{tabular}

The means followed by same lower case letters in the columns and capital letter in the lines do not differ statistically from each other at $5 \%$ probability level for Scott-Knott test. Source: Authors.

At Table 4 we may see the Mean Germination Time (MGT) of barley seed. In this case, as smaller the numbers as better. Maintaining the comparison, MGT before application was bigger than over the period after application and without application. During evaluation time after application, MGT have decreased until 14 DAA, but seeds harvested at natural 
physiologic maturation presented increment in MGT of $16 \%$ for BRS Cryst; $15,6 \%$ for BRS Demeter; $14,2 \%$ for BRS Kallibre and $10,2 \%$ for BRS Sampa.

Table 4. Mean Germination Time (MGT - Days) of barley seed at the end of experiment, seven days after sowing, in three different harvest situations: seeds harvested at plants submitted to pre-harvest dessication with glyphosate $\left(480 \mathrm{~g} \mathrm{~L}^{-1}\right.$ of active ingredient) at dose $5 \mathrm{~L} \mathrm{ha}^{-1}$, sampled in six different time after application (DAA - Days after application); seeds harvested at plants before glyphosate application (105 DAS - Days after sowing in field) and seeds harvested at plants without application (128 DAS - Days after sowing in field).

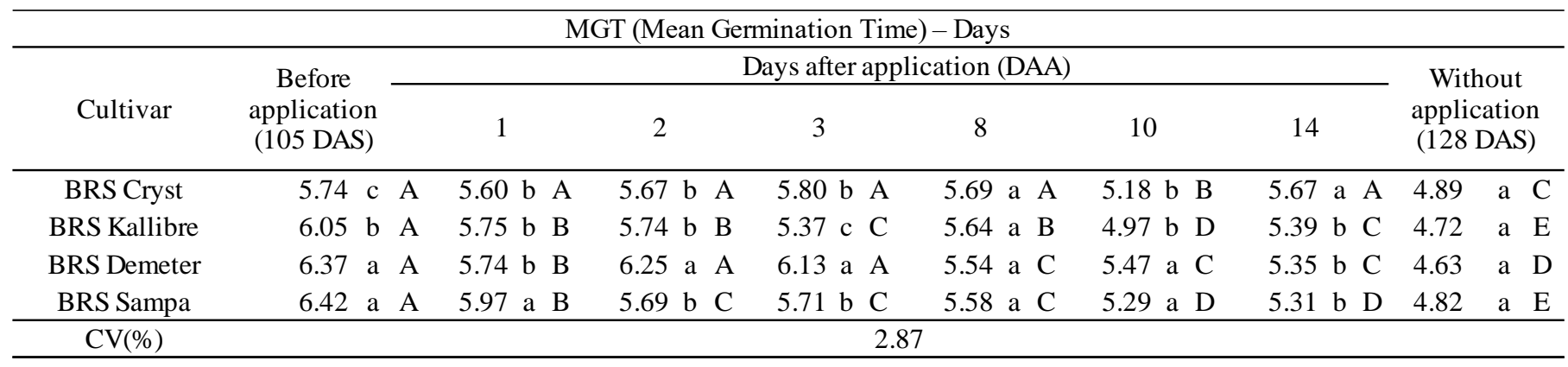

The means followed by same lower case letters in the columns and capital letter in the lines do not differ statistically from each other at $5 \%$ probability level for Scott-Knott test. Source: Authors.

The number of seeds germinated per day (Mean Germination Speed - MGS) also have been influenced by glyphosate application (Table 5).

Although before application (105 DAS) have noticed the smallest percentage of germination (Table 2), until 14 DAA the MGS was constant, but comparing to treatment without application (128 DAS) less seed have germinated per day for all cultivars.

Table 5. Mean Germination Speed (MGS - Days ${ }^{-1}$ ) of barley seed at the end of experiment, seven days after sowing, in three different harvest situations: seeds harvested at plants submitted to pre-harvest dessication with glyphosate $\left(480 \mathrm{~g} \mathrm{~L}^{-1}\right.$ of active ingredient) at dose $5 \mathrm{~L} \mathrm{ha}^{-1}$, sampled in six different time after application (DAA - Days after application); seeds harvested at plants before glyphosate application (105 DAS - Days after sowing in field) and seeds harvested at plants without application (128 DAS - Days after sowing in field).

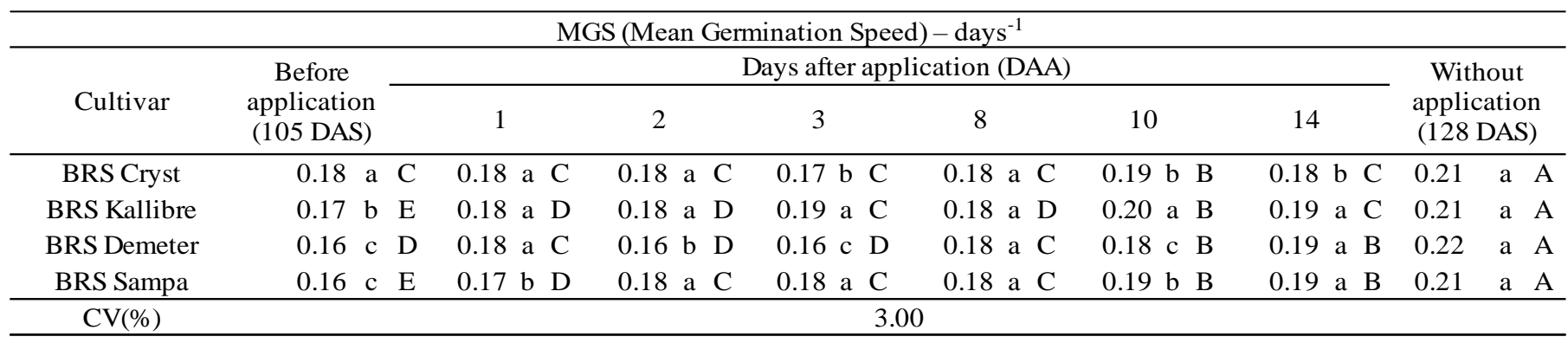

The means followed by same lower case letters in the columns and capital letter in the lines do not differ statistically from each other at $5 \%$ probability level for Scott-Knott test. Source: Authors.

The seedling length have showed different behaviour until now (Table 6). Seedlings of BRS Demeter and BRS Sampa have not differed statistically from the eighth day after the application of glyphosate until the fourteenth day and also in 
relation to the treatment without application. In the other hand, BRS Cryst and BRS Kallibre have presented bigger seedlings only in treatment without application.

Table 6. Seedlings length $(\mathrm{cm})$ of barley seed at the end of experiment, seven days after sowing, in three different harvest situations: seeds harvested at plants submitted to pre-harvest dessication with glyphosate (480 $\mathrm{g} \mathrm{L}^{-1}$ of active ingredient) at dose $5 \mathrm{~L} \mathrm{ha}^{-1}$, sampled in six different time after application (DAA - Days after application); seeds harvested at plants before glyphosate application (105 DAS - Days after sowing in field) and seeds harvested at plants without application (128 DAS -

\begin{tabular}{|c|c|c|c|c|c|c|c|c|c|}
\hline \multicolumn{10}{|c|}{ Seedling length $-\mathrm{cm}$} \\
\hline \multirow[b]{2}{*}{ Cultivar } & \multirow{2}{*}{\multicolumn{2}{|c|}{$\begin{array}{c}\text { Before } \\
\text { application } \\
\text { (105 DAS) }\end{array}$}} & \multicolumn{6}{|c|}{ Days after application (DAA) } & \multirow{2}{*}{$\begin{array}{c}\text { Without } \\
\text { application } \\
\text { (128 DAS) }\end{array}$} \\
\hline & & & 1 & 2 & 3 & 8 & 10 & 14 & \\
\hline BRS Cryst & 15.96 & a $\mathrm{B}$ & 13.22 a C & 9.02 a D & 10.41 a $D$ & $16.69 \mathrm{~b} \mathrm{~B}$ & $21.35 \mathrm{a} \mathrm{A}$ & 17.13 a $B$ & 22.34 a $\mathrm{A}$ \\
\hline BRS Kallibre & 11.251 & b $\mathrm{D}$ & 10.99 b D & 11.55 a $\mathrm{D}$ & 9.52 a $D$ & $17.09 \mathrm{~b} \mathrm{~B}$ & 20.31 a $\mathrm{A}$ & $14.20 \mathrm{~b} \mathrm{C}$ & 22.37 a A \\
\hline BRS Demeter & 10,831 & b $\mathrm{B}$ & $9.83 \mathrm{~b} \quad \mathrm{~B}$ & 9.39 a $\mathrm{B}$ & 8.77 a $\mathrm{B}$ & 20.79 a A & $19.08 \mathrm{~b} \mathrm{~A}$ & 19.52 a $\mathrm{A}$ & 21.10 a $\mathrm{A}$ \\
\hline BRS Sampa & 4.401 & $\mathrm{~b} B$ & $6.66 \mathrm{c} \mathrm{C}$ & 9.70 a $\mathrm{B}$ & 9.52 a $\mathrm{B}$ & $17.72 \mathrm{~b} \mathrm{~A}$ & $17.75 \mathrm{~b} \mathrm{~A}$ & 18.52 a $\mathrm{A}$ & $18.98 \quad \mathrm{~b} \quad \mathrm{~A}$ \\
\hline $\mathrm{CV}(\%)$ & \multicolumn{9}{|c|}{11.34} \\
\hline
\end{tabular}

Days after sowing in field).

The means followed by same lower case letters in the columns and capital letter in the lines do not differ statistically from each other at $5 \%$ probability level for Scott-Knott test. Source: Authors.

At Table 7 it is possible to analyse the percentage of normal seeding after submit seeds to accelerated ageing. As the percentage of germinated seed in normal conditions (Table 2), the accelerated ageing also have shown difference in all treatments. The reduction of normal seedling when harvested in early days decreased the number but also increased over the evaluated period after application. However, without applications, even at accelerated ageing, have presented the highest mean of normal seedlings.

Table 7. Percentage of normal seedlings of barley seed submitted to accelerated ageing, seven days after sowing, in three different harvest situations: seeds harvested at plants submitted to pre-harvest dessication with glyphosate $\left(480 \mathrm{~g} \mathrm{\textrm {L } ^ { - 1 }}\right.$ of active ingredient) at dose $5 \mathrm{~L} \mathrm{ha}^{-1}$, sampled in six different time after application (DAA - Days after application); seeds harvested at plants before glyphosate application (105 DAS - Days after sowing in field) and seeds harvested at plants without application (128 DAS - Days after sowing in field).

\begin{tabular}{|c|c|c|c|c|c|c|c|c|c|c|}
\hline \multicolumn{11}{|c|}{ Accelerated ageing - \% of normal seedling } \\
\hline \multirow[b]{2}{*}{ Cultivar } & \multirow{2}{*}{$\begin{array}{c}\text { Before } \\
\text { application } \\
\text { (105 DAS) }\end{array}$} & & \multicolumn{6}{|c|}{ Days after application (DAA) } & \multirow{2}{*}{\multicolumn{2}{|c|}{$\begin{array}{l}\text { Without } \\
\text { application } \\
\text { (128 DAS) }\end{array}$}} \\
\hline & & & 1 & 2 & 3 & 8 & 10 & 14 & & \\
\hline BRS Cryst & $33.5 \mathrm{a}$ & $\mathrm{C}$ & $29.0 \mathrm{~b} \quad \mathrm{D}$ & $34.0 \mathrm{~b} \mathrm{C}$ & $26,5 \mathrm{~b} \quad \mathrm{D}$ & 37.3 c C & 46.5 c B & $50.0 \mathrm{~b} \quad \mathrm{~B}$ & 89.0 & $\mathrm{a} A$ \\
\hline BRS Kallibre & $26.5 \mathrm{a}$ & $\mathrm{E}$ & 43.0 a $\mathrm{D}$ & 44.5 a $\mathrm{D}$ & 46.5 a $\mathrm{D}$ & 61.5 a $\mathrm{C}$ & 75.0 a $B$ & 73.0 a $\mathrm{B}$ & 93.5 & a $\mathrm{A}$ \\
\hline BRS Demeter & $5.0 \mathrm{~b}$ & $\mathrm{E}$ & 19.5 c D & $33.0 \mathrm{~b} \mathrm{C}$ & $31.0 \mathrm{~b} \mathrm{C}$ & $43.0 \mathrm{~b} \quad \mathrm{~B}$ & 49.5 с B & $50.0 \mathrm{~b} \mathrm{~B}$ & 99.0 & a $\mathrm{A}$ \\
\hline BRS Sampa & $27.0 \mathrm{a}$ & $\mathrm{D}$ & $22.5 \mathrm{c} \mathrm{D}$ & 41.5 a $\mathrm{C}$ & $29.0 \mathrm{~b} \quad \mathrm{D}$ & $48.0 \mathrm{~b} \mathrm{C}$ & $65.0 \mathrm{~b} \quad \mathrm{~B}$ & 67.0 a B & 92.0 & a A \\
\hline $\mathrm{CV}(\%)$ & \multicolumn{10}{|c|}{11.16} \\
\hline
\end{tabular}

The means followed by same lower case letters in the columns and capital letter in the lines do not differ statistically from each other at $5 \%$ probability level for Scott-Knott test. Source: Authors. 
The synchronization index (Table 8) have shown that all cultivars presented means over one to seeds harvested in plants with application of glyphosate in all samples and for BRS Cryst and BRS Kallibre at plants without application. For BRS Demeter and BRS Sampa before application and seeds harvested in plants without glyphosate application, for all cultivars, synchronization index presented means less than one (Table 8).

Table 8. Synchronization index - SI (bits) of barley seed at the end of experiment, seven days after sowing, in three different harvest situations: seeds harvested at plants submitted to pre-harvest dessication with glyphosate $\left(480 \mathrm{~g}^{-1}\right.$ of active ingredient) at dose $5 \mathrm{~L} \mathrm{ha}^{-1}$, sampled in six different time after application (DAA - Days after application); seeds harvested at plants before glyphosate application (105 DAS - Days after sowing in field) and seeds harvested at plants without application

\begin{tabular}{|c|c|c|c|c|c|c|c|c|c|}
\hline \multirow[b]{3}{*}{ Cultivar } & \multicolumn{8}{|c|}{ Synchronization index (SI) - bits } & \multirow{3}{*}{$\begin{array}{c}\text { Without } \\
\text { application } \\
\text { (128 DAS) }\end{array}$} \\
\hline & \multirow{2}{*}{\multicolumn{2}{|c|}{$\begin{array}{c}\text { Before } \\
\text { application } \\
\text { (105 DAS) }\end{array}$}} & \multicolumn{6}{|c|}{ Days after application (DAA) } & \\
\hline & & & 1 & 2 & 3 & 8 & 10 & 14 & \\
\hline BRS Cryst & $1.72 \mathrm{a}$ & $\mathrm{B}$ & 1.58 a B & 1.58 a B & $1.18 \mathrm{~b} \mathrm{C}$ & 1.63 a $\mathrm{B}$ & 2.05 a $\mathrm{A}$ & 1.42 a B & 0.95 a C \\
\hline BRS Kallibre & $1.25 \mathrm{~b}$ & $\mathrm{~B}$ & $1.54 \mathrm{a} \mathrm{A}$ & 1.75 a $\mathrm{A}$ & 1.97 a $\mathrm{A}$ & $1.37 \mathrm{a} \mathrm{B}$ & 1.75 a $\mathrm{A}$ & 1.16 a B & $0.63 \quad b \quad C$ \\
\hline BRS Demeter & $0.98 \mathrm{c}$ & $\mathrm{D}$ & 1.62 a $\mathrm{A}$ & $1.30 \mathrm{a} \mathrm{B}$ & $1.36 \mathrm{~b} \mathrm{~B}$ & 1.47 a B & 1.89 a $\mathrm{A}$ & 1.07 a C & $0.45 \quad \mathrm{~b} \quad \mathrm{D}$ \\
\hline BRS Sampa & $0.81 \mathrm{c}$ & $\mathrm{B}$ & $0.88 \mathrm{~b} \quad \mathrm{~B}$ & $1.60 \mathrm{a} \mathrm{A}$ & $1.90 \mathrm{a} \mathrm{A}$ & 1.24 a B & 1.96 a A & $1.04 \mathrm{a} \mathrm{B}$ & $0.86 \quad \mathrm{a} \quad \mathrm{B}$ \\
\hline $\mathrm{CV}(\%)$ & & & & & 20. & & & & \\
\hline
\end{tabular}

(128 DAS - Days after sowing in field).

The means followed by same lower case letters in the columns and capital letter in the lines do not differ statistically from each other at $5 \%$ probability level for Scott-Knott test. Source: Authors.

\section{Discussion}

The results were very clear in relation to glyphosate application in pre-harvest of barley seeds: the herbicide greatly affected the seeds vigour.

The first count test is important because it assesses the germination speed, indicating that the higher the seed germination in the first count, the greater its vigour (Nakagawa, 1999). In this case, the first count, at 4 DAS, showed more vigorous seeds in the treatment without applying glyphosate to detriment of others, as well as there was an increase in the percentage at the first count over the period after application. There was an increase in the percentage, however, at the end of the 14 days the final average was much lower in relation to the treatment without application. The same occurred with the percentage of final germination, at 7 DAS, the application of glyphosate interfered in the formation of the seed interrupting maturation or decreasing, as it is possible to observe that there was an increase in the first count and final germination until 14 DAA.

Marcos-Filho (2015) reports that the early harvest in relation to the time of maturity, causes deficiency in the performance of the seeds. Interfering with physiological quality, as they are not formed, with less accumulation of dry mass, resulting in low vigour seeds.

During seed maturation, the acquisition of desiccation tolerance may coincide with physiological maturity. The ability to germinate after harvest precedes the development of this ability in relation to rapid artificial drying (Hong-Bo et al., 2005), which was not the case in the present study, in which desiccation greatly interfered in barley germinative power, making generalization impossible, as noted, each species will behave in a different way.

The first count and the germination speed index (GSI) may be used to identify batches with faster emergence in the field or in the greenhouse, thus minimizing the adverse conditions that occur during germination and seedling establishment 
(Nascimento \& Pereira, 2007), these lower values obtained in seeds harvested before application and seeds harvested in plants to which glyphosate was applied, in the first count and IVG, may be explained by the fact that these seeds have lesser amount of reserve material as maturation was interrupted.

The chemical plants desiccation proved to be efficient in anticipating the harvest of bean seeds, when compared to the control without desiccation (Kappes et al., 2009), however, as well as Krenchinski et al. (2017), tested the quality of wheat seeds in desiccation in pre-harvest, the authors also found decreased germination, corroborating with the present study.

From the physiological maturity, the photoassimilates translocation from the plant to seed is stopped (Marcos Filho, 2015). In this sense, the application of pre-harvest herbicides should not compromise seeds physiological quality. However, in cultures that desiccate, such as soybeans and beans, the seeds are protected by the pod and in the case of corn, there is straw. However, in barley, the seeds are exposed in the panicle and at the moment of application they receive the product directly and therefore they may be more sensitive. Barros et al. (2019) working with sorghum also discovered that glyphosate is harmful to seed germination, the same found in the present work.

Bervald et al. (2010) have reported, in studies with soybean seeds, that the damage caused after glyphosate use are severe. According to these authors, when applied directly to the seeds, local absorption may occur, in addition to molecules further degradation and formation of secondary metabolites such as AMPA (aminomethylphosphonic acid), which may be accumulated in the seeds and trigger disturbances that lead to the formation of abnormal seedlings.

Furthermore, mobility through phloem is one of the most important glyphosate characteristics, with translocation through the leaves to other organs, including stem and roots. This herbicide affects secondary metabolites synthesis due to the shikimic acid route blockage. Among the damages caused to the plant, it is possible to mention the effects on the synthesis of indolacetic acid (IAA) and other plant hormones are reported, in the synthesis of chlorophyll, phytoalexins and lignin, protein synthesis, photosynthesis, respiration, transpiration, membrane permeability (Sherwani et al., 2015). In other words, there is an interruption of plant development the that will consequently affect seeds ripening.

The Mean Germination Time (MGT) is a characteristic that reflects growth and performance in the subsequent development stages of species under natural conditions, being a crucial factor in the survival and establishment of the species. Jefferson and Pennachio (2005) published that plants that germinate more slowly may be reduced in size and, as a result of being more susceptible to stress, predation affecting less chance of competition for resources. This information was proved when we analyse the values of seedling length. It is important to note that higher MGT have generated smaller seedlings. The same was observed to Mean Germination Speed (MGS), where the mean of germinated seed per day was smaller when applied the glyphosate in pre-harvest.

The initial seeds quality influenced seedling length, and high vigour seedlings obtained the highest length, in comparison with those originating from medium and low vigour seedlings. The results found in this work are in accordance with those described by Nakagawa (1999), who concluded that normal seedlings or parts of them that presented longer average length are generated from vigorous seeds.

Many authors (Funguetto et. al., 2004, Bervald et. al., 2010, Daltro et. al., 2010) have reported the decrease of germinative power, seedling length, MGT and MGS applying glyphosate in soy bean, which means that this herbicide is harmful to any kind of species independent of families.

Accelerated ageing (AA) is a way of simulating seeds physiological potential, after a certain period of storage. It is considered as a vigour test and its main objective is to identify seeds tolerance to stress. This test follows the pattern of germination test, however, in most cases the results obtained in it are inferior to those of germination, as the seeds are subjected to a stress before being placed to germinate. Uses a methodology which associates two sources of stress, namely, 
high humidity and high temperature, which at the field level are generally never ideal, therefore, they infer the germination results obtained in the laboratory (Marcos Filho, 2015).

However, in this work, we may describe some different situations in relation what was cited previously. In seeds harvested before application, the percentage of normal seedling in AA was bigger than the germination in normal conditions. The same has happened to seeds harvested after application until eight days, which means that the stress caused by AA treatment (seeds kept in gerbox on aluminum screen over water, at $41^{\circ} \mathrm{C}$, for 24 hours) probably interfered in seed physiologic maturation which increased the germination ratio, but not enough to achieve the germination ratio of seed harvested without glyphosate application.

The synchronization index (SI), as the name implies, informs the synchronicity in which seeds germinate and, according to Santana and Ranal (2004), the lower the number, the more synchronized the seed germination will be. An advantage of this index is that it does not take into account the total number of germinated seeds, or the mean germination time, or germination speed. In this case, the lowest values of SI was found in seeds harvested in plants without glyphosate application.

The SI was higher in treatments with a higher germination percentage, which means there was no synchronicity in the germination of these seeds. An exception was in relation to seeds of cultivars BRS Demeter and BRS Sampa, which had lower values of synchronization index. This may be explained as these cultivars showed extremely low germination percentage, which may have interfered in the calculation of synchronization index, as in the period that comprised the test there was germination of $14.5 \%$ and $7 \%$, respectively.

The lowest SI was observed in seeds harvested from plants that were not desiccated with glyphosate. As previously exemplified, glyphosate interfered in seeds final development, generating immature embryos with little vigour that led to the uncontrolled seeds germination of plants treated with this herbicide.

The measurement unit for this index is bits, as $\log _{2}$ is used. Each bit is a binary measure that counts, in this case, germination and non-germination; thus, the transformation of the relative frequency for each observation time into a logarithm of the frequency in base 2 transforms a mass binary measure (Ranal \& Santana, 2006), making it possible to quantify the synchrony, where the higher the value, the lower the synchrony.

\section{Conclusion}

Glyphosate (480 $\mathrm{g} \mathrm{L}^{-1}$ of active ingredient), at dose of $5 \mathrm{~L} \mathrm{ha}^{-1}$, has interfered negatively in the physiological maturation of barley seeds when the herbicide was applied in pre-harvest at 105 days after sowing.

The results obtained showed that there was an increase in seeds germination after 14 days of application, however, the means were significantly smaller in relation to seeds harvested at the point of physiological maturation (128 days after sowing) without glyphosate application.

\section{Acknowledgments}

The authors would like to thank the Experimental Farm outsourced staff for the services performed in conducting the field experiment.

\section{References}

Barros, A. F., Pimentel, L. D., Freitas, F. C. L., Cecon, P. R., Tomaz, A. C., Sousa, E. A. M., Ladeira, L. M. \& Biesdorf, E. M. (2019). Dessecação précolheita em sorgo granífero: qualidade fisiológica das sementes e efeito sobre a rebrota. Revista Brasileira de Ciências Agrárias, 14(2), e5655. https://doi.org/10.5039/agraria.v14i2a5655. 
Bervald, C. M. P., Mendes, C. R., Timm, F. C., Moraes, D. M., Barros, A. C. S. A. \& Peske, S. T. (2010). Desempenho fisiológico de sementes de soja de cultivares convencional e transgênica submetidas ao glifosato. Revista Brasileira de Sementes, 32(2), 9-18. https://doi.org/10.1590/S010131222010000200001 .

Brasil. (2009). Regras para análise de sementes. MAPA/ ACS.

Brunharo, C. A. C., Christoffoleti, P. J. \& Nicolai, M. (2014). Aspectos do mecanismo de ação do amônio glufosinato: culturas resistentes e resistência de plantas daninhas. Revista Brasileira de Herbicidas, 13(2), 163-177.

Carvalho, N. M. \& Nakagawa, J. (2000). Sementes: ciência, tecnologia e produção. Funep.

Daltro, E. M. F., Albuquerque, M. C. F., França Neto, J. B., Guimarães, S. C., Gazziero, D. L. P. \& Henning, A. A. (2010). Aplicação de dessecantes em précolheita: efeito na qualidade fisiológica de sementes de soja. Revista Brasileira de Sementes, 32(1), 111-122. http://dx.doi.org/10.1590/S010131222010000100013

Edmond, J. B. \& Drapalla, W. J. (1958). The effects of temperature, sand and soil, and acetone on germination of okra seed. Proceedings of the American society for Horticultural Science, 71, 428-443.

Ferreira, D. F. (2019). Sisvar: a computer analysis system to fixed effects split plot type designs. Revista Brasileira de Biometria, 37(4), 529-535. https://doi.org/10.28951/rbb.v37i4.450.

Funguetto, C. I., Tillmann, M. A. A., Villela, F. A. \& Dode, L. B. (2004). Detecção de sementes de soja geneticamente modificada tolerante ao herbicida glifosato. Revista Brasileira de Sementes, 26(1), 130-138. http://dx.doi.org/10.1590/S0101-31222004000100020.

Hong-Bo, S., Zong-Suo, L. \& Ming-An, S. (2005). LEA proteins in higher plants: structure, function, gene expression and regulation. Colloids and Surfaces B: Biointerfaces, 45(3-4), 131-135.

Jefferson, L. V. \& Pennachio, M. (2005). Allelopathic effects of foliage extracts from four Chenopodiaceae species on seed germination. Journal of Arid Environmentes, 55(2), 275-285. https://doi.org/10.1016/S0140-1963(03)00028-4.

Kappes, C., Carvalho, M. A. C. \& Yamashita, O. M. (2009). Potencial fisiológico de sementes de soja dessecadas com Diquat e Paraquat. Scientia Agraria, 10(1), 001-006.

Krenchinski, F. H., Cesco, F. J. L., Rodrigues, D. M., Pereira, V. G. C, Albrecht, A. J. P. \& Albrecht, L. P. (2017). Yield and physiological quality of wheat seeds after desiccation with different herbicides. Journal of Seed Science, 39(3), 254-261. http://dx.doi.org/10.1590/2317-1545v39n3172506.

Labouriau, L. G. \& Pacheco, A. (1978). On the frequency of isothermal germination in seeds of Dolichos biflorus L. Plant and Cell Physiology, 19(3), 507512.

Maguire, J. D. (1962). Speed of germination - aid in selection and evaluation for seedling emergence and vigor. Crop Science 1: 176-177. 1962.

Marcos Filho, J. (2015). Fisiologia de sementes de plantas cultivadas. FEALQ.

Nakagawa, J. (1999). Testes de vigor baseados no desempenho das plântulas. In: Krzyzanowski, F. C., Vieira, R. D. \& França, N. J. B. (Eds.). Vigor de sementes: conceitos e testes. ABRATES.

Narwal, S., Kumar, D., Kharub, A. S., \& Verma, R. P. S. (2020). 11 -Barley biofortification: Present status and future prospects. In O. P. Gupta, V. Pandey, S. Narwal, P. Sharma, S. Ram, \& G. P. Singh (Orgs.), Wheat and Barley Grain Biofortification (p. 275 - 294). Woodhead Publishing. https://doi.org/10.1016/B978-0-12-818444-8.00011-0.

Nascimento, W. M. \& Pereira, R. S. (2007). Testes para avaliação do potencial fisiológico de sementes de alface e sua relação com a germinação sob temperaturas adversas. Revista Brasileira de Sementes, 29(3), 175-179.

Oliveira, G. P. \& Morais, O. M. (2019). Maturação e qualidade fisiológica de sementes de feijão-caupi. Agropecuária Científica no Semiárido, 15(1), 23-34. http://dx.doi.org/10.30969/acsa.v15i1.1006.

Pessenti, I. L., Torres, A. L., Martins, W. S., Macoski, N. (2021). Manejo nutricional com micronutrientes e seus efeitos sobre os componentes de produtividade na cevada. Research, Society and Development, 10(3), e30910313225. http://dx.doi.org/10.33448/rsd-v10i3.13225.

Ranal, M. A. \& Santana, D. G. 2006. How and why to measure the germination process? Revista Brasileira de Botânica, 29(1):1-11. https://doi.org/10.1590/S0100-84042006000100002.

Santana, D. G. \& Ranal, M. A. (2004). Análise da germinação: um enfoque estatístico. Editora UNB.

Santos, H. G., Jacomine, P. K. T., Anjos, L. H. C., Oliveira, V. A., Lumbreras, J. F., Coelho, M. R., Almeida, J. A., Araújo Filho, J. C., Oliveira, J. B. \& Cunha, T. J. F. (2018). Sistema Brasileiro de Classificação de Solos. Embrapa.

Seidler, E. P., Velho, J. P., Christofari, L. F., Almeida, P. S. G. \& Andreatta, T. (2019). Dessecação em pré-colheita do trigo: nova preocupação para a qualidade do cereal no consumo humano. Scientia Agraria Paranaensis, 18(3), 200-208. https://doi.org/10.18188/sap.v18i3.21203.

Sherwani, S. I., Arif, I. A. \& Khan, H. A. (2015). Modes of action of different classes of herbicides. In: Price, A., Kelton, J.; Sarunaite, L. (Eds.). Herbicides, physiology of action, and safety. InTech Publishers. https://doi.org/10.5772/61779.

Tavares, L. C., Lemes, E. S., Brunes, A. P., Oliveira, S. de, Mendonça, A. O. de, \& Villela, F. A. (2018). Suplementação de boro na semeadura e no perfilhamento em cevada: Amazonian Journal of Agricultural and Environmental Sciences, 61, 1-7. 
Research, Society and Development, v. 10, n. 7, e24310716469, 2021

(CC BY 4.0) | ISSN 2525-3409 | DOI: http://dx.doi.org/10.33448/rsd-v10i7.16469

Vergara, R. O., Monteiro, R. C. M., Gadotti, G. I. \& Moreira, I. B. (2020). Temperatura de secagem e qualidade de sementes de arroz. Brazilian Journal of Development, 6(4), 22524-22530. http://dx.doi.org/10.34117/bjdv6n4-424.

Wild, A., Sauer, H. \& Ruhle, W. (1987). The efect of phosphinothricin (glufosinate) on photosynthesis. Z. Naturforsch, 42(3), $263-269$.

Zavariz, A., Berryhill, Q. T. A., Guimarães, E. T. \& Pereira, F. A. C. (2020). A utilização de glifosato no cultivo de café, um estudo epistemiológico. Brazilian Journal of Development, 6(6), 36046-36058. https://doi.org/10.7824/rbh.v19i2.705. 